\begin{abstract}
Humboldt University of Berlin, Faculty of Agriculture and Horticulture, Institute of Animal Sciences, Department of Breeding Biology and Molecular Animal Breeding ${ }^{1}$, Institute of Animal Husbandry and Breeding, Centre for Moleculare Medicine, Berlin', Germany
\end{abstract}

\author{
CHRISTA BRUNSCH', UTE PHILIPP', PETER REINECKE', GERHARD MOSER ${ }^{2}$, \\ HERMANN GELDERMANN ${ }^{2}$, KARLA KOEPKE ${ }^{3}$, WOLFGANG LEUCHT ${ }^{1}$ \\ and HELMUT STIER'†
}

\title{
A new strategy of heterosis research in mice - approach and results on chromosome 19
}

\author{
Dedicated to Prof. Dr. Dr. h.c. Gottfried Leuthold on the occasion of his $65^{\text {th }}$ birthday
}

\section{Summary}

The following steps were performed to analyse heterosis and QTL effects in litter size of mice: intercross of mouse inbred strains $\mathrm{C} 57 \mathrm{BL} / 6 \mathrm{~J}$ and $\mathrm{Balb} / \mathrm{cJ}$ in order to produce a $\mathrm{F}_{2}$ generation with 948 female animals; selection of trait groups with extreme high ((13 offspring) and extreme low litter size ( 5 offspring)); typing of 56 microsatellites with an average distance of $32 \mathrm{cM}$; detection of different chromosome regions with associations to heterosis in litter size. Chromosome 19 was associated to heterosis in litter size. Additional animals with extreme high and low litter sizes were then typed for four DNA markers on chromosome 19 and used for QTL mapping. A QTL was identified for litter size in segment D19Mit28 - D19Mit99 with a maximum at $15 \mathrm{cM}$ $(\mathrm{p} \leq 0.05)$. The QTL explains about $11 \%$ of the phenotypic variance in the $\mathrm{F}_{2}$ generation. With a degree of dominance of 4.09 the QTL shows that superdominance can explain heterosis in litter size.

Key words: heterosis, fertility, mouse, DNA marker, QTL

\section{Zusammenfassung}

Titel der Arbeit: Eine neue Strategie der Heterosis-Forschung an Mäusen - methodischer Ansatz und Ergebnisse auf Chromosom 19

Die folgenden Schritte wurden zur Analyse der Heterosis und zum Nachweis von QTL-Effekten für die Wurfgröße bei der Maus durchgeführt: Intercross der Mäuse-Inzuchtstämme C57BL/6J und Balb/cJ zur Bildung einer $\mathrm{F}_{2}$-Generation mit 948 weiblichen Tieren; Selektion von Tieren verschiedener Leistungsgruppen mit extrem hoher und niedriger Wurfgröße (13 bzw. 5 Nachkommen); Typisierung von 56 Mikrosatelliten in einem durchschnittlichen Abstand von $32 \mathrm{cM}$; Identifizierung von Chromosomenregionen mit Beziehung zur Heterosis für Wurfgröße. Chromosom 19 war mit Heterosis für Wurfgröße assoziiert. Daraufhin wurden zusätzliche Tiere mit extrem hohen und niedrigen Wurfgrößen für vier DNA-Marker auf Chromosom 19 typisiert und für die QTL-Kartierung benutzt. Es wurde ein QTL für Wurfgröße im Segment D19Mit28-D19Mit99 mit einem Maximum bei $15 \mathrm{cM}$ gefunden $(\mathrm{p} \leq 0.05)$. Der QTL erklärt ca. $11 \%$ der phänotypischen Varianz in der $\mathrm{F}_{2^{-}}$ Generation. Für den QTL zeigte ein Dominanzgrad von 4,09 , daß Superdominanz die Heterosis für Wurfgröße
erklären kann.

Schlüsselwörter: Heterosis, Fruchtbarkeit, Maus, DNA-Marker, QTL

\section{Introduction}

Heterotic effects are highly significant for animal breeding. As well known, trait values, which improve fitness of animals, are highly influenced by non-additive effects. For example, fertility is a trait with low heritability and indicates large heter- 
otic effects (GÖTZ et al., 1991). Different types of crosses are suitable for the utilisation of heterosis whereas recurrent reciprocal selection (RRS) can improve nonadditive effects. For RRS, the combination effects are measured from trait values after test matings of appropriate parents in the cross offspring. Test matings in farm animals increase the generation interval, cause financial losses and need high organization effort (LEE, 1997; BARBOSA-NETO et al., 1997). However, test crosses can be avoided, if homozygosity of DNA loci responsible for heterosis can be analysed in parents (LEUTHOLD, 1968). Superdominance, dominance, linkage and epistasis are assumed to be reasons for heterosis. Hardly another phenomenon of genetics is conflicted with numerous contradictory hypotheses as heterosis (POONI and TREHARNE, 1994; XIAO et al., 1996; STUBER, 1997). Molecular methods offer the possibility to verify the hypotheses of heterosis and to analyse the genetic basis of heterosis (TSAFTARIS, 1995). QTLs for traits with heterotic effects have been identified in plants (e.g. MITCHELL-OLDS, 1995; ARMSTEAD et al., 1997). Similar investigations are still missing in animals. In the work presented, DNA markers were used for QTL analysis of heterosis in litter size.

\section{Material and Methods}

\subsection{Approach of heterosis analysis}

The long term heterosis project is divided in three parts (Fig. 1). Litter size (number of total born animals, two litters) was used as selection criterium for fertility. Project part I is described in detail by BRUNSCH et al. (1997) and PHILIPP (1997). Reciprocal recurrent selection in part II of the project is directed to complementary homozygosity in the two lines.

In project part I, associations between a number of loci and litter size were analysed. Additional loci were considered for positions of chromosomes which had significant effects on litter size and genotyped in a larger number of animals (project part III). In the following contribution, first results are presented from project parts I and III.

\section{2}

\section{Cross of the inbred lines C57BL/6J x Balb/cJ}

The inbred lines $\mathrm{C} 57 \mathrm{BL} / 6 \mathrm{~J}$ and Balb/cJ (Fig. 1) were mated reciprocally and subsequently the $F_{1}$ animals were intercrossed. Animals of inbred lines were purchased from Bomholtgard Breeding and Research Centre, Denmark. The $\mathrm{F}_{2}$ generation consisted of 948 animals. Two extreme trait groups of litter size were selected from the $948 \mathrm{~F}_{2}$ mice (18 animals with 13 offspring and 14 animals with 5 offspring). In part III additional animals with high or low litter sizes were included for QTL analysis of chromosome 19 (49 animals: 12 offspring; 49 animals: 7 offspring).

\section{3}

DNA analysis

In project part I two sets of DNA loci have been considered (PHILIPP, 1997): (1) 19 microsatellites which are localized close to loci with known associations to fertility, (2) 


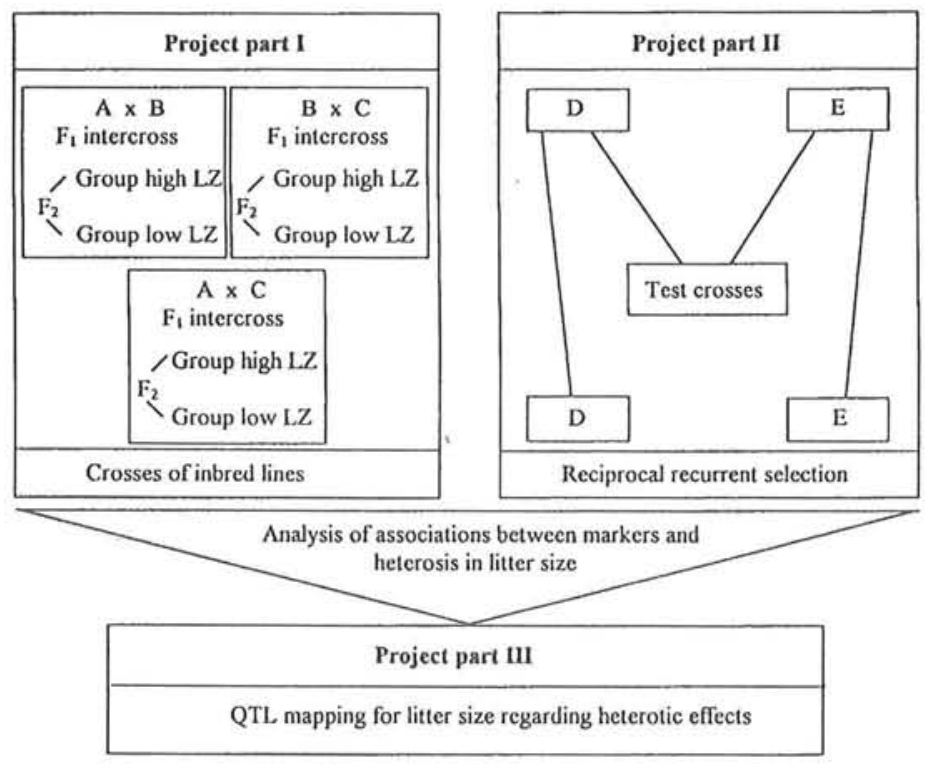

Fig. 1: Approach of heterosis analysis in mice (Ansatz zur Heterosisforschung bei Mäusen) LZ: litter size

A, B, C: inbred lines C56BL/6J, Balb/cJ, NMRI/DKFZ

$D, E$ : outbred lines, selected from $F_{2}$ animals of cross $\mathrm{A} \times \mathrm{B}$

32 microsatellites evenly distributed throughout the genome. Additional markers were typed according to the results of project part I on chromosome 19 for which associations to heterosis were found. The microsatellites had an average distance of 14 $\mathrm{cM}$ on chromosome 19 (total length $55.7 \mathrm{cM}$ ) and the positions $3 \mathrm{cM}$ (D19Mit93), 12 cM (D19Mit28), $20 \mathrm{cM}$ (D19Mit98) and $41 \mathrm{cM}$ (D19Mit99). Distances between loci are taken from Mouse Genome Database, August 1998.

The microsatellites were PCR amplified with non-labeled primers $\left(1 \times 180 \mathrm{~s} 94^{\circ} \mathrm{C} ; 25\right.$ x $\left.\left\{15 \mathrm{~s} 94^{\circ} \mathrm{C}, 120 \mathrm{~s} 56^{\circ} \mathrm{C}, 120 \mathrm{~s} 72{ }^{\circ} \mathrm{C}\right\} ; 1 \times 350 \mathrm{~s} 72{ }^{\circ} \mathrm{C}\right)$ and PCR products were separated in a $12 \%$ polyacrylamide gel (Sequencing equipment SS1000, Fröbel, Wasserburg and electrophoretical equipment Blue Vertical 160C, Serva, Heidelberg). The staining of separated PCR products by silver nitrate followed (BASSAM et al., 1991).

4.4 Statistical analysis

The analysis of associations between genotypes of microsatellite loci and heterosis was performed using two models: superdominance $(\mathrm{AA}<\mathrm{Aa}>\mathrm{aa})$ or dominance $(\mathrm{AA}=\mathrm{Aa}>\mathrm{aa}$.). Associations between the degree of heterozygosity and litter size were investigated by Chi square tests according to PEARSON (SPSS, Version 6.1). In cases of observations per genotype smaller than five, the Exact Test has been used. The 
CRI-MAP software of GREEN et al. (1990) was applied for linkage mapping. QTL mapping was performed using an interval mapping approach. Chromosome specific thresholds were estimated via permutation analysis. A Bonferroni correction was applied to obtain genome-wide thresholds.

5.

Results

Heterotic effects. Litter sizes for inbred strains, $F_{1}$ and $F_{2}$ generations are shown in Figure 2. Heterotic effects were $45.3 \%$ in the $\mathrm{F}_{1}$ and $15.1 \%$ in the $\mathrm{F}_{2}$ generation.

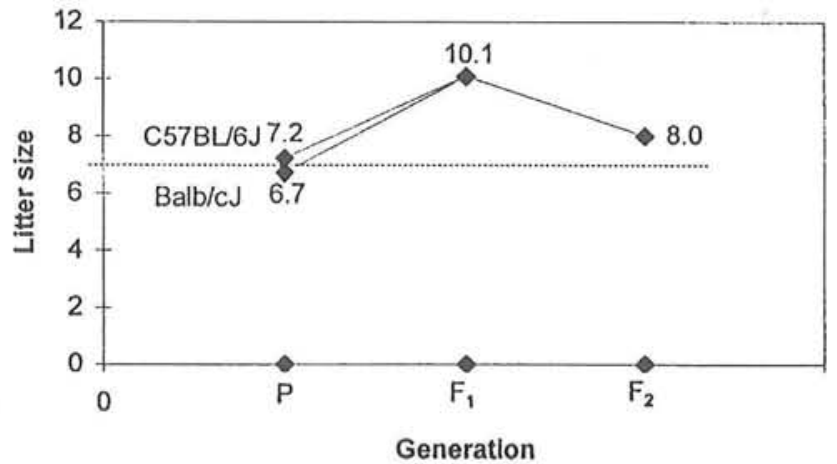

Fig. 2: Litter sizes in the inbred lines, $F_{1}$ and $F_{2}$ generation (Wurfgrößen der Inzuchtlinien, $F_{1}-$ und $F_{2}$ Generation)

Associations between DNA markers on chromosome 19 and heterosis in litter size.

Table 1 gives the significant associations between the degree of heterozygosity of microsatellites and litter size in the extreme trait groups.

Table 1

Heterozygosity of microsatellites on chromosome 19 in the extreme trait groups of litter size (Heterozygotie der Mikrosatelliten auf Chromosom 19 der extremen Merkmalsgruppen für Wurfgröße)

\begin{tabular}{lcccc}
\hline $\begin{array}{l}\text { Micro- } \\
\text { satellite }\end{array}$ & $\begin{array}{c}\text { Localisation" } \\
\text { on chromosome 19 } \\
(\mathrm{cM})\end{array}$ & $\begin{array}{c}\text { Degree of heterozygosity (\%) } \\
\text { Low litter size (n=14) }\end{array}$ & $\mathrm{p}^{2)}$ \\
\hline D19Mit28 & 12 & 89 & 43 & 0.008 \\
D19Mit61 & 8 & 89 & 43 & 0.008 \\
\hline $\begin{array}{l}\text { T) Mouse Genome Databasc (MGD), August 1998 } \\
\text { ") Exact Test (SPSS, Version 6.1, Exact) }\end{array}$
\end{tabular}

Linkage mapping of chromosome 12. The linkage map of chromosome 19 is shown in Figure 3.

QTL mapping for litter size. The plot of the test statistic (Figure 4) suggested a QTL for litter size on chromosome 19 in the interval D19Mit28 - D19Mit99 with the most likely position at $15 \mathrm{cM}$. Table 2 summarises the results of QTL analysis. 


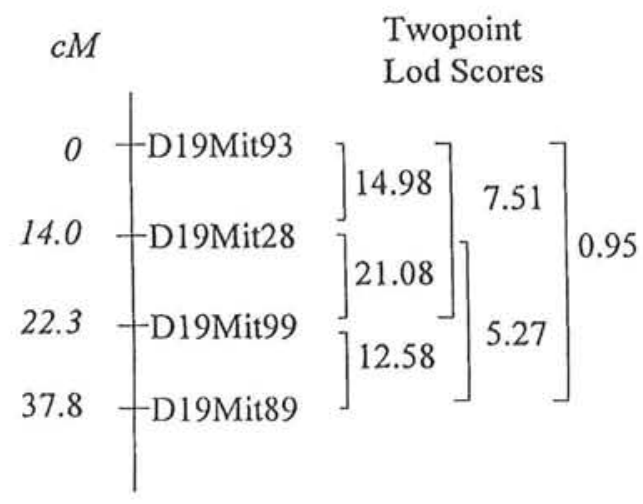

Fig. 3: The linkage map of chromosome 19 (Kopplungskarte von Chromosom 19)

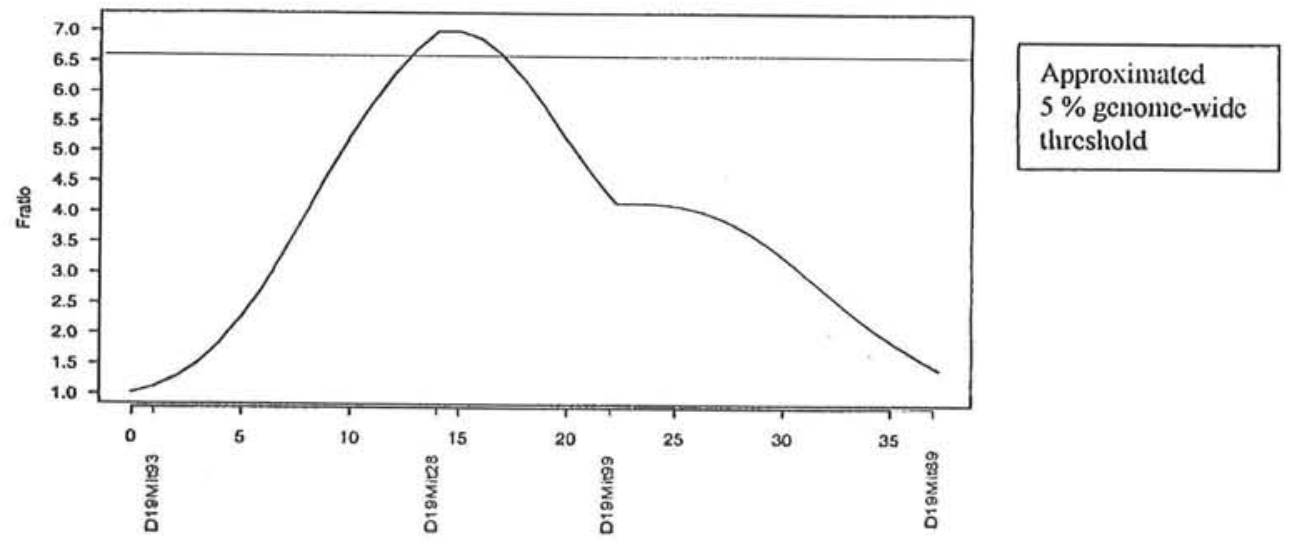

Fig. 4: Interval mapping on mouse chromosome 19 (Intervallkartierung von Chromosom 19 der Maus)

Table 2

Summary of QTL analysis on chromosome 19 (Zusammenfassung der QTL-Analyse auf Chromosom 19)

$\begin{array}{lc}\text { F ratio } & 7.01 \\ \mathrm{~F}_{2} \text { variance } & \\ & 10.92 \\ \text { Dominance effect (d) } & \\ \pm \text { S.E. } & 3.00 \\ & \pm 0.83 \\ \text { Additive effect (a) } & \\ \pm \text { S.E. } & 0.733 \\ & \pm 0.59 \\ \text { Degree of dominance (d/a) } & 4.09\end{array}$


6. Discussion

Mice are advantageous for heterosis research because of a short generation interval, small expenditure of housing, numerous inbred strains and abundant well characterised DNA markers. The litter size is a major parameter of fertility in mice as well as in all farm animals like pig. In agreement with literature data, high heterotic effect for litter size have been observed after cross of the inbred lines C57BL/6J and Balb/cJ (Fig. 2). So far four of 20 analysed chromosomes were associated with heterosis in litter size. Chromosome 19 was chosen for this study since the microsatellites D19Mit28 and D19Mit61 differed largely in their degrees of heterozygosity between the high and low trait groups and are in agreement with superdominance.

For linkage and QTL mapping of chromosome 19 additional animals and markers have been included. The calculated linkage map is in agreement with the MGD (1998). The results of QTL mapping strongly suggest the presence of a QTL on chromosome 19 at position $15 \mathrm{cM}$. The QTL explains about $11 \%$ of the phenotypic variance in the $\mathrm{F}_{2}$ generation. As a potential candidate gene of this chromosome region, the gene Relaxin with association to fertility is located at position $21 \mathrm{cM}$ (MGD, August 1998). The high degree of dominance (4.09) shows that superdominance causes heterosis in litter size. Information on QTL obtained from mice can be transferred to farm animals. It seems possible to define DNA markers which are homologous between mice and other mammalian species and test them for heterosis in fertility. After identification of the responsible genes they can be used for breeding on non-additive gene effects.

\section{Acknowledgement}

We thank C. Look, I. Schlumpberger, E. Friedel, S. Neumann, I. Sternstein, R. Schiefler, G. Piepke and H. Hoeft for the laboratory analyses respectively the care of the mice experiments.

\section{References}

ARMSTEAD, I.; JIANG, C.; HAYWARD, M.; LAFITTE, H.R.; EDMEADES, G.O.; HOISINGTON, D.; DEUTSCH, J.A.:

Genetic analysis of adaptation differences between highland and lowland tropical maize. The Genetics and Exploitation of Heterosis in Crops. Heterosis in Crops. International Symposium, August 17-22 (1997), Mexico City, Mexico

BARBOSA-NETO, J.F.; SORRELLS, M.E.; CISAR, G.:

Prediction of heterosis in wheat using coefficient of parentage and RFLP-based estimates of genetic relationship. The Genetics and Exploitation of Heterosis in Crops. Heterosis in Crops. International Symposium, August 17-22 (1997), Mexico City, Mexico

BASSAM, B.; CAETANO-ANOLLES, G.; GRESSHOFF, P.:

Fast and sensitive silver staining of DNA in polyacrylamide gels. Analytical Biochemistry 196 (1991), 80-83

BRUNSCH, C.; PHILIPP, U.; HORNER, S.; LEUTHOLD, G.; REINECKE, P.; KOEPKE, K.; FRIEDEL, E.; LOOK, C.; GREIFENBERG, I.; SCHIEFLER, R.; STIER, H.; LEUCHT, W.:

Associations between DNA-Markers and heterosis in litter size in different mice inbred line crosses. Beijing International Conference on Animal Biotechnology, Peoples Republic of China, June 11-14 (1997), Proceedings of international conference on animal biotechnology: 265-268 
GÖTZ, K.U.; GLODEK, P.; RAPP, K.:

Crossbreeding effects after long-term selection for purebred performance: a model experiment with mice. Theor. Appl. Genet. 81 (1991), 720-728

GREEN, P., FALLS, K., CROOKS, S.:

Documentation for CRIMAP Version 2.4 (1990), Waschington University School of Medicine, St. LEE, M.:

Louis, Polycopy

Towards understanding and manipulating heterosis in crops - can molecular genetics help? The Genetics and Exploitation of Heterosis in Crops. Heterosis in Crops. International Symposium, August 17-22, (1997), Mexico City, Mexico

LEUTHOLD, G.:

Genetische Grundlagen moderner Züchtungsverfahren in der Haustierzucht. Arch. Tierz., Berlin 11 (1968) 1, 3-25

MITCHELL-OLDS, T.:

Interval mapping of viability loci causing heterosis in Arabidopsis. Genetics 140 (1995), 1105-1109

Mouse Genome Database (1998):

PHILIPP, U.:

http $\backslash$ :mgd.hgmp.mrc.ac.uk

Charakterisierung von Heterosiseffekten für Wurfgröße durch DNA-Marker-Analysen. HumboldtUniversität zu Berlin, Diss., 1997

POONI, H.S.; TREHARNE, A.J.:

The role of epistasis and background genotype in the expression of heterosis. Heredity 72 (1994), 628635

STUBER, C.W.:

Biology and physiology of heterosis. The Genetics and Exploitation of Heterosis in Crops. Heterosis in Crops. International Symposium, August 17-22 (1997) Mexico City, Mexico

TSAFTARIS, S.A.:

Molecular aspects of heterosis in plants. Physiologia Plantarium 94 (1995), 362-370

XIAO, J.; LI, J.; YUAN, L.; McCOUCH, S.R.; TANKSLEY, S.D.:

Genetic diversity and its relationship to hybrid performance and heterosis in rice as revealed by PCRbased markers. Theor. Appl. Genet. 92 (1996), 637-643

Received: 12.10 .1999

Accepted: 23.11 .1998

Author's addresses

Dr. CHRISTA BRUNSCH, Dr. UTE PHILIPP, Dr. PETER REINECKE,

Dr. WOLFGANG LEUCHT, Dr. HELMUT STIER $\dagger$

Humboldt-Universität zu Berlin, Landwirtschaftlich-Gärtnerische Fakultät

Institut für Nutztierwissenschaften

Fachgebiet Züchtungsbiologie und Molekulare Tierzüchtung

Philippstr. 13

D-10115 Berlin, Germany

Dr. KARLA KOEPKE

Max Delbrück Centrum

Arbeitsgemeinschaft Genomforschung

Robert-Rössle-Str. 10

D-13122 Berlin, Germany

Prof. Dr. HERMANN GELDERMANN, Dr. GERHARD MOSER

Universität Hohenheim, Institut für Tierhaltung und Tierzüchtung

Fachgebiet Tierzüchtung und Biotechnologie

Garbenstr.17

D-70599 Stuttgart, Germany 
Arch. Tierz., Dummerstorf 42 (1999) 1, 110

Buchbesprechung

Unsere Pferde - gesund durch Homöopathie

\section{MICHAEL RAKOW}

2. unveränderte Auflage, 224 Seiten, Sonntag Verlag, Stuttgart, 1998, ISBN 3-87758-170-6, 59,-- DM, 431,ÖS, 53,50 SFr

Naturheilkundliche Heilmethoden finden auch in der Tiermedizin zunehmend mehr Beachtung. Da nur wenig gute Fachliteratur verfügbar ist, die eine gute homöopathische Therapie beim Pferd ermöglicht, ist es ein besonderes Verdienst des Autors mit diesem Nachschlagewerk und Kompendium bessere Möglichkeiten homöopathischer Therapie aufzuzeigen. Dabei stützt er sich auf bewährte Standardwerke, vor allem aber auf seine langjährigen Erfahrungen in der homöopathischen Tiermedizin. Dieses Buch kann in der Aus- und Weiterbildung vor allem aber dem praktischen Tierarzt helfen die Symptome und homöopathischen Mittel zu finden, die zur Auffindung des heilenden Arzneimittels wichtig sind.

Nach einer Einführung in die Grundprinzipien homöopathischer Praxis, werden die wichtigsten Krankheitskomplexe, Erkrankungen und ihre homöopathische Behandlung beschrieben. Dabei wurde besonderer Wert auf die ausführliche Darstellung der Symptome gelegt, die bei einer bestimmten Erkrankung und einer bestimmten Symptomatik für die Arzneimittelwahl ausschlaggebend sind. Zum besseren Verständnis findet sich jeweils zu Beginn der Hauptkapitel, nach einer kurzen Erklärung des klinischen Sachverhaltes, eine Zusammenfassung der Fragen, die für einen bestimmten Krankheitskomplex relevant sind und es werden die für die Arzneimittelwahl wichtigen Symptome und vor allem Modalitäten aufgezeigt. Die Hauptabschnitte umfassen die Therapie der Atemwegserkrankung, der Krankheiten des Magen - Darmtraktes, des Bewegungsapparates, die Behandung von Verletzungen, die Therapie bei Verhaltensstörungen und die homöopathische Geburtshilfe. Für die einzelnen Erkrankungen folgen nach Beschreibung der Ätologie, die Symptomatologie und Therapie, gefolgt vom Spektrum möglicher Arzneimittel. Bei den jeweiligen Therapiekonzepten findet bei der Wahl eines homöopathischen Heilmittels die Gesamtheit der Symptome Berücksichtigung. Im Anhang finden sich Aussagen zum Arzneimittelrecht, zu homöopathischen Fachausdrücken sowie ein Arzneimittel-, Indikations- und Literaturverzeichnis. Dieses Buch macht deutlich, daß man bei der homöopathischen Therapie von Pferden immer auf die genaue Beobachtung des Tieres durch den Tierhalter sowie den Tierarzt angewiesen ist. Durch die gute didaktische Aufbereitung kann dieses praxisrelevante Buch den notwendigen Beobachtungsaustausch zwischen Tierhalter und Tierarzt erheblich verbessern. Für den praktischen Tierarzt stellt das Buch eine Orientierungshilfe dar, die es ihm besser ermöglicht wichtige Angaben der Anamnese nicht zu übersehen, und es kann wesentlich zum Erfolg homöopathischer Heilmethoden beitragen. Es bereichert das Spektrum veterinärhomöopathischer Fachliteratur und ist einem breiten Leserkreis von Pferdehaltern und Tierärzten sehr zu empfehlen.

ERNST RITTER, Dummerstorf 